\title{
Hemostatic assessment of dogs associated with hepatic parasite load of Leishmania infantum chagasi
}

Avaliação hemostática de cães associada com a carga parasitária hepática de Leishmania infantum chagasi

Mariana de Medeiros Torres ${ }^{1 *}$; Arleana do Bom Parto Ferreira de Almeida ${ }^{1}$; Daphine Ariadne Jesus de Paula ${ }^{1}$;

Adriane Jorge Mendonça ${ }^{1}$; Luciano Nakazato ${ }^{1}$; Caroline Argenta Pescador ${ }^{1}$; Valéria Régia Franco Sousa ${ }^{1}$

${ }^{1}$ Departamento de Clínica Médica Veterinária, Universidade Federal de Mato Grosso - UFMT, Cuiabá, MT, Brasil

Received August 11, 2015

Accepted October 11, 2015

\begin{abstract}
Leishmania infantum chagasi liver parasite load was compared to hemostatic abnormalities, as well as to clinical, laboratorial, and histopathological findings in dogs with visceral leishmaniasis. The liver parasite load of $30 \operatorname{dogs} L$. infantum chagasi naturally-infected was evaluated by quantitative real- time PCR and the results were compared with serum biochemistry and primary and secondary hemostasis findings. Moreover, hepatic histological lesions were described in these dogs. Prolonged bleeding time, prothrombin time (PT), and activated partial thromboplastin time (APTT), were observed in the group with visceral leishmaniasis. Eleven dogs presented inflammatory liver lesions, with predominance of mild multifocal mononuclear periportal hepatitis. No association between the presence of parasites and abnormalities in screening tests was observed by Spearman's rank correlation coefficient. The clinical progression in leishmaniasis is associated with the occurrence of hemorrhagic diathesis, which depends not only on the presence of the parasite but also the inflammatory process, compromised immunological response, hepatic and renal failure in symptomatic dogs.
\end{abstract}

Keywords: Coagulation, leishmaniasis, liver, qPCR.

\section{Resumo}

A carga parasitária de Leishmania infantum chagasi do fígado foi comparada às anormalidades hemostáticas, bem como aos achados clínicos, laboratoriais e histopatológicos em cáes com leishmaniose visceral. A carga parasitária do fígado de 30 cães naturalmente infectados por $L$. infantum chagasi foi avaliada por PCR quantitativo em tempo real e os resultados foram comparados com bioquímica sérica e achados de hemostasia primária e secundária. Além disso, foram descritas as lesóes hepáticas nestes cáes. Prolongado tempo de sangramento, tempo de protrombina (TP) e tempo de tromboplastina parcial ativada (TTPA) foram observados no grupo com leishmaniose visceral. Onze cães apresentaram lesōes inflamatórias no fígado, predominando hepatite periportal mononuclear multifocal. Não foi observada associação entre a presença de parasitos e as anormalidades nos testes laboratoriais por correlação de Spearman. A progressão clínica na leishmaniose está associada com a ocorrência de diátese hemorrágica, que depende não só da presença do parasito, mas também do processo inflamatório, do comprometimento da resposta imunológica e da falência renal e hepática em cães sintomáticos.

Palavras-chave: Coagulaçáo, leishmaniose, fígado, qPCR.

Canine visceral leishmaniasis (CVL) is a multisystemic disease which infects humans, wild animals and domestic dogs (CIARAMELLA et al., 2005; SARIDOMICHELAKIS, 2009).

Dogs can develop nonspecific clinical signs, as apathy, lack of appetite, dermatosis, lymphadenomegaly and in severe cases hemostatic, kidney and hepatic abnormalities. Hemostatic abnormalities may cause thrombocytopenia, prolonged prothrombin time (PT) and activated partial thromboplastin time (APTT), increased fibrinogen

*Corresponding author: Mariana de Medeiros Torres. Hospital Veterinário, Universidade Federal de Mato Grosso - UFMT, Avenida Fernando Correa, s/n, CEP 78060-900, Cuiabá, MT, Brasil. e-mail: marys_torres@hotmail.com and fibrin degradation products occur frequently (MORENO, 1999; SOLANO-GALLEGO et al., 2001; CIARAMELLA et al., 2005).

Detection of parasite load by quantitative real-time PCR (qPCR) studies, and the assessment of hemostasis in dogs with CVL with clinical trials, has been widely studied. Regardless it is unknown if the hemostatic abnormalities are related to parasitism by Leishmania, especially in liver, which has an outstanding function in coagulation (MANNA et al., 2009). Therefore, the aim of this study was to compare the liver parasite load (LPL) with hemostatic disorders, laboratory and histopathological findings in canine visceral leishmaniasis. 
A prospective study was carried out with 30 L. infantum chagasi (CVL group) seropositive dogs diagnosed by IFAT/ ELISA tests (Biomanguinhos FIOCRUZ, Rio de Janeiro, RJ, Brazil). This CVL group comprised 15 males and 15 females with an average age of 3.9 years (ranging from eight months to 14 years) and of the following breeds: Pinscher (4/30), Belgian Shepherd (1/30), Pit Bull (6/30), Rottweiler (1/30) and mongrel dogs (18/30), with IFAT titres ranging from 1: 80 to 1: 640 .

A control group consisting of 13 dogs (nine males and four females) with ages ranging from two to six years old and of the following breeds: Poodle (3/ 13), Lhasa Apso (3/ 13), Boxer (1/ 13) and mongrel dogs (6/13) was formed for reference of biochemical and hemostatic parameters. These dogs were considered healthy after clinical and laboratory examination, as hematology, serum biochemistry, PCR and IFAT.

Samples of blood and bone marrow obtained from the manubrium of the sternum of dogs in both groups were submitted to molecular detection of Ehrlichia canis e Anaplasma platys (ALMEIDA et al., 2010). In CVL group Leishmania sp. was also detected by PCR approach and posteriorly the $L$. infantum chagasi specie was characterized by RFLP- PCR (ANDRADE et al., 2006).

For the secondary hemostasis tests, $5 \mathrm{ml}$ of citrated blood samples were centrifuged at 2,069 $\mathrm{g}$ for $5 \mathrm{~min}$. The extrinsic and common pathways evaluated by PT (Soluplastin; Wiener Lab, Rosario, Argentina), the intrinsic and common pathways evaluated by APTT (APTT; Wiener Lab, Rosario, Argentina), and fibrinogen concentration (Fibrinogen; Wama Diagnóstica, São Carlos, SP, Brazil) were determined in duplicate in a semi-automatic coagulometer through the optical detection system by laser emission (CLOTimer Laser Sensor; CLOT, Sorocaba, SP, Brazil).

Bleeding time (BT) was measured through small incision in the clean and hairless internal side of the ear and the estimate platelet number was determined through blood smear from the ear tip. Total counting was performed in Neubauer chamber after dilution (1:200) in Rees Eckert reagent within four hours of total blood collection.

Serum samples of CVL and control groups were submitted to a kinetic/ colorimetric assay in a semi-automatic analyzer (SB - 190; Celm, São Caetano do Sul, SP, Brazil) using commercial kits (Gold Analisa Diagnóstica; Belo Horizonte, MG, Brazil) to determine urea, creatinine, alanine aminotransferase (ALT), alkaline phosphatase (AP), albumin and globulin concentrations.

According to Brazilian Ministry of Health specifications, seropositive dogs were euthanized. After necropsy, two liver fragments were collected of each animal: one was fixed in $10 \%$ formaline for histopathological examination, and the other fragment was stored at $-20{ }^{\circ} \mathrm{C}$ for DNA extraction and subsequent parasite quantification by qPCR.

Liver samples were processed routinely according to the methods for histopathological analysis. Briefly, the tissues were fixed in neutral- buffered formalin solution for 72 hours, processed and stained with hematoxylin and eosin (TAFURI et al., 2004). The analysis at optical microscopy was based on the identification of amastigotes and presence of hepatic lesions concomitant to CVL.

Quantitative qPCR from liver samples was carried out in triplicate using the Sequence Detection System Step One Real Time PCR Systems (Applied Biosystems). For accurate sensitivity kinetoplast DNA was chosen as the molecular target. The assay mixtures was prepared in a $15 \mu \mathrm{L}$ final volume, containing SYBR Green Master Mix, $0.3 \mu \mathrm{M}$ of each primer (150 [sense] 5' - GGG (G/T) AGGGGCGTTCT (C/G) CGAA - 3' and 152 [antisense] 5' (C/G) (C/G) (C/G) (A/T) CTAT (A/T) TTACACCAACCCC - 3’), and $1 \mu \mathrm{L}$ of DNA template. The amplification conditions included an initial incubation step at $94^{\circ} \mathrm{C}$ for $10 \mathrm{~min}$, followed by 40 amplification cycles, of $94^{\circ} \mathrm{C}$ for $15 \mathrm{~s}$ and $60{ }^{\circ} \mathrm{C}$ for $60 \mathrm{~s}$. The reaction showed efficiency of $99 \%(R 2=0,972 \varepsilon=99,548$ and Slope $=-3,333)$ with melting temperatures of $84^{\circ} \mathrm{C}$.

The standard curves was stablished from kDNA of Leishmania sp. cloned in the plasmid from $2.8 \times 10^{8}$ molecules/ $\mu \mathrm{L}$, ranging from 10 a $10^{7}$ parasites in each reaction until the detection limit was reached (QUARESMA et al., 2009).

The results were submitted to normality test with Kolmogorov-Smirnov test. To compare serum biochemistry between groups we used the Student's $t$ test, whereas the non-parametric Mann Whitney test was employed to analysis hemostatic alterations. Spearman's rank correlation coefficient was used to correlate parasite load and hemostatic parameters with histopathological alterations in CVL group. For all statistical analyses, $\mathrm{p} \leq 0.005$ was used to determine statistical significance with the aid of the statistics program GraphPad Prism v. 4.0.

In the CVL group, all dogs were Leishmania positive in at least one collection site by molecular techniques. The positive samples were submitted to PCR-RFLP approach to confirm the presence of $L$. infantum chagasi. The coinfection with $E$. canis and $A$. platys was excluded in all groups through PCR approach.

All dogs of the CVL group were classified as symptomatic $(12 / 30)$ and oligo symptomatic (18/30), however none of the dogs presented clinical manifestations of coagulation disorders.

The biochemical tests demonstrated azotemia in $26.66 \%$ of the CVL dogs, however statistical differences were observed only for the globulin increase, albumin decrease and AP in dogs from CVL group $(\mathrm{p} \leq 0.05)$ (Table 1$)$. Whereas, $53.33 \%$ dogs showed thrombocytopenia and increased BT in the hemostasis tests, with no correlation between these parameters $(\mathrm{r}=-0.28)$.

Comparing groups, alterations in PT and APTT were observed in CVL group, with a frequency of 30\% in APTT test and of $23.33 \%$ in PT, however the fibrinogen concentration was lower in $16.66 \%$ of the dogs, which consequently resulted in a prolonged clotting time. However, statistical difference was observed when comparing CVL and control groups only with fibrinogen concentration ( $\mathrm{p}=0.005)$.

Remarkable hepatic inflammatory lesions were diagnosed in 11 dogs (Figure 1), including multifocal mononuclear periportal hepatitis characterized as mild (29.62\%), moderate $(7.40 \%)$, and severe $(3.70 \%)$, also severe and diffuse hepatocyte swelling in one dog.

Despite the lesions described, there were no statistical correlation between hemostatic abnormalities and the liver parasite load (Table 2).

The absence of hemorrhagic diathesis observed in dogs with leishmaniasis contradicts previous findings reported in coagulation studies with similar number of dogs evaluated (MORENO, 1999; CIARAMELLA et al., 2005). This difference may be related to the disease clinical evolution, which depends not only on the presence of 
Table 1. Summary statistics for serum biochemical tests in CVL and control groups.

\begin{tabular}{|c|c|c|c|}
\hline Parameters & $C V L n=30$ & Control $n=13$ & p-value* \\
\hline \multicolumn{4}{|l|}{ Albumin (g/dL) } \\
\hline Mean & 1.66 & 3.43 & 0.0001 \\
\hline Median & 1.65 & 3.30 & \\
\hline SD & 0.46 & 0.41 & \\
\hline \multicolumn{4}{|l|}{$\operatorname{ALT}(\mathrm{UI} / \mathrm{L})$} \\
\hline Mean & 34.70 & 36.62 & 0.78 \\
\hline Median & 25.50 & 34.00 & \\
\hline SD & 21.89 & 16.74 & \\
\hline \multicolumn{4}{|l|}{ Creatinine $(\mathrm{mg} / \mathrm{dL})$} \\
\hline Mean & 1.31 & 1.10 & 0.22 \\
\hline Median & 1.20 & 1.10 & \\
\hline SD & 0.62 & 0.20 & \\
\hline \multicolumn{4}{|l|}{$\mathrm{AP}(\mathrm{UI} / \mathrm{L})$} \\
\hline Mean & 84.93 & 34.77 & 0.004 \\
\hline Median & 55.50 & 29.00 & \\
\hline SD & 85.22 & 23.50 & \\
\hline \multicolumn{4}{|l|}{ Globulin (g/dL) } \\
\hline Mean & 5.80 & 3.30 & 0.0001 \\
\hline Median & 5.90 & 2.90 & \\
\hline SD & 1.40 & 1.03 & \\
\hline \multicolumn{4}{|l|}{ Urea (mg/dL) } \\
\hline Mean & 72.93 & 38.23 & 0.19 \\
\hline Median & 46.50 & 36.00 & \\
\hline SD & 94.23 & 11.48 & \\
\hline
\end{tabular}

*Studant's t test, significance $\mathrm{p} \leq 0.005$.

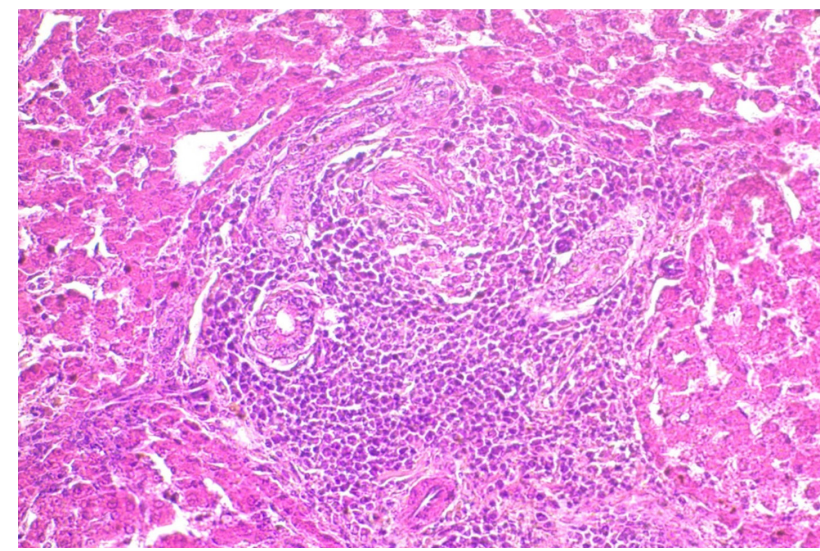

Figure 1. Inflammatory infiltrate composed of mononuclear cells in liver. HE (40X).

Table 2. Hemostatic parameters and liver parasite load in dogs with visceral leishmaniasis.

\begin{tabular}{lcccc}
\hline & \multicolumn{2}{c}{ Hepatic lesion } & p-value & \multirow{2}{*}{ r* $^{*}$} \\
\cline { 2 - 3 } & Present & Absent & & - \\
\cline { 1 - 2 } $\begin{array}{l}\text { LPL (copies) } \\
\text { parasites) }\end{array}$ & $1.4 \times 10^{5}$ & $1.4 \times 10^{6}$ & 0.29 & - \\
PT (s) & 8.22 & 20.62 & 0.04 & -0.09 \\
APTT (s) & 18.87 & 31.60 & 0.38 & -0.02 \\
Fibrinogen $(s)$ & 102.3 & 128.6 & 0.14 & -0.16 \\
BT (s) & 25.01 & 33.15 & 0.77 & 0.008 \\
\hline
\end{tabular}

LPL: liver parasite load; PT: prothrombin time; APTT: activated partial thromboplastin time; BT: bleeding time. ${ }^{*}$ Spearman r. s - seconds. the protozoan, but also of the inflammatory process, compromised immunological response and renal and hepatic failure occurring in markedly symptomatic dogs (CIARAMELLA et al., 2005).

Despite the absence of hemorrhagic diathesis, an increase of APTT in 30\% of dogs and of PT in dogs without histological lesion was observed. However, hepatic alterations suggested in serum biochemistry do not corroborate these findings. The granulomatous cellular immune response is essential for the elimination of parasites in the liver, which could justify the load found in dogs without lesion and hemostatic abnormalities (CARTER et al., 2007).

In CVL, subclinical hepatitis frequently occurs (RALLIS et al., 2005), however this is the first study that correlate hepatic lesions, parasite load and biochemical parameters. Nevertheless, considering only the presence or absence of liver lesion it is possible to note that even in the absence of any type of histological lesion the amount of parasites and the hemostatic disorders are pronounced.

Despite variation in the copy number of Leishmania kDNA, higher amounts were found in liver samples, mainly in those without hepatic lesion. Therefore, the histological lesions commonly observed in CVL and associated with increased serum activity of ALT and AP (TAFURI et al., 2001), were not related with hemorrhagic diathesis or the presence of parasite.

Using the qPCR technique is possible to establish the relationship between increased parasite load and severe clinical manifestation of leishmaniasis, and associate high titres of specific antibodies (MANNA et al., 2009). Similar results were found in our study, 
and although no correlation was observed between parasite load and antibody titres, 60\% of the dogs showed titres of 1:640.

Therefore, considering serology as a sensitive method, well correlated with clinical signs (SOLANO-GALLEGO et al., 2001) and the absence of histological lesions, we suggest that in these dogs, the immunological response has more influence over the severity of clinical signs that lead to hemorrhagic disorders.

Bleedings may occur in severe clinical conditions, when the immune system is compromised during chronic inflammation, and the hepatic damage is progressive, influencing platelet function and the synthesis and metabolism of the coagulation factors (CORONA et al., 2004).

Hyperglobulinemia associated with hypoalbuminemia is one of the main characteristics of canine leishmaniasis (SARIDOMICHELAKIS, 2009). The deposition of immune complexes on the vascular wall impairs the endothelium resulting in platelet disorders (CIARAMELLA et al., 2005), as observed in the majority $(53.33 \%)$ of dogs with prolonged BT and antibody titres ranging from 1:80 to 1:640. High concentrations of gamma globulins, which are related to a polyclonal response of B-lymphocytes, may reflect in the presence of parasite-specific antibodies and also in autoimmune reaction (CIARAMELLA et al., 2004).

In conclusion, the hepatic lesions, even mild, induce abnormalities in secondary hemostasis tests. Moreover, parasite load does not influence the hemorrhagic disorders which may be more related to the differences in the individual inflammatory response in clinical forms of leishmaniasis.

\section{Ethics}

The study was approved by the institutional Animal Care and Use Committee (CEUA protocol number 23108.014734/10-0, Universidade Federal de Mato Grosso).

\section{References}

Almeida ABPF, Paula DAJ, Dutra V, Nakazato L, Mendonça AJ, Sousa VRF. Infecção por Ehrlichia canis e Anaplasma platys em cadelas e neonatos de Cuiabá, Mato Grosso. Arch Vet Sci 2010; 15(3): 127-134.

Andrade HM, Reis AB, Santos SL, Volpini AC, Marques MJ, Romanha AJ. Use of PCR-RFLP to identify Leishmania species in naturally-infected dogs. Vet Parasitol 2006; 140(3-4): 231-238. http://dx.doi.org/10.1016/j. vetpar.2006.03.031. PMid:16682124.

Carter KC, Henriquez FL, Campbell SA, Roberts CW, Nok A, Mullen $\mathrm{AB}$, et al. DNA vaccination against the parasite enzyme gammaglutamylcysteine synthetase confers protection against Leishmania donovani infection. Vaccine 2007; 25(22): 4502-4509. http://dx.doi. org/10.1016/j.vaccine.2007.03.014. PMid:17418459.
Ciaramella P, Cortese L, Corona M, Ambrosio R, Di Loria A, Persechino A. Plasma thrombomodulin levels in dogs naturally infected with Leishmania infantum. Vet Res Commun 2004;28(S1 Suppl 1): 327-330. http://dx.doi. org/10.1023/B:VERC.0000045438.09357.13. PMid:15372989.

Ciaramella P, Pelagalli A, Cortese L, Pero ME, Corona M, Lombardi $\mathrm{P}$, et al. Altered platelet aggregation and coagulation disorders related to clinical findings in 30 dogs naturally infected by Leishmania infantum. Vet J2005; 169(3): 465-467. http://dx.doi.org/10.1016/j.tvjl.2004.03.009. PMid:15848791.

Corona M, Ciaramella P, Pelagalli A, Cortese L, Pero ME, Santoro D, et al. Haemostatic disorders in dogs naturally infected by Leishmania infantum. Vet Res Commun 2004;28(S1 Suppl 1): 331-334. http://dx.doi. org/10.1023/B:VERC.0000045439.46994.1f. PMid:15372990.

Manna L, Reale S, Vitale F, Gravino AE. Evidence for a relationship between Leishmania load and clinical manifestations. Res Vet Sci 2009; 87(1): 76-78. http://dx.doi.org/10.1016/j.rvsc.2008.12.009. PMid:19178919.

Moreno P. Evaluation of secondary haemostasis in canine leishmaniasis. Vet Rec 1999; 144(7): 169-171. http://dx.doi.org/10.1136/vr.144.7.169. PMid:10097324.

Quaresma PF, Murta SMF, Ferreira EC, Rocha-Lima ACVM, Xavier AAP, Gontijo CMF. Molecular diagnosis of canine visceral leishmaniasis: Identification of Leishmania species by PCR-RFLP and quantification of parasite DNA by real-time PCR. Acta Trop 2009; 111(3): 289-294. http://dx.doi.org/10.1016/j.actatropica.2009.05.008. PMid:19467216.

Rallis T, Day MJ, Saridomichelakis MN, Adamama-Moraitou KK, Papazoglou L, Fytianou A, et al. Chronic hepatitis associated with canine leishmaniosis (Leishmania infantum): a clinicopathological study of 26 cases. J Comp Pathol 2005; 132(2-3): 145-152. http://dx.doi.org/10.1016/j. jcpa.2004.09.004. PMid:15737341.

Saridomichelakis MN. Advances in the pathogenesis of canine leishmaniosis: epidemiologic and diagnostic implications. Vet Dermatol 2009; 20(56): 471-489. http://dx.doi.org/10.1111/j.1365-3164.2009.00823.x. PMid:20178485.

Solano-Gallego L, Morell P, Arboix M, Alberola J, Ferrer L. Prevalence of Leishmania infantum infection in dogs living in an area of canine leishmaniasis endemicity using PCR on several tissues and serology. J Clin Microbiol 2001; 39(9): 560-563. http://dx.doi.org/10.1128/ JCM.39.2.560-563.2001. PMid:11158106.

Tafuri WL, Oliveira MR, Melo MN, Tafuri WL. Canine visceral leishmaniosis: a remarkable histopathological picture of one case reported from Brazil. Vet Parasitol 2001; 96(3): 203-212. http://dx.doi.org/10.1016/ S0304-4017(00)00436-2. PMid:11240094.

Tafuri WL, Santos RL, Arantes RME, Gonçalves R, de Melo MN, Michalick MS, et al. An alternative immunohistochemical method for detecting Leishmania amastigotes in paraffin-embedded canine tissues. JImmunol Methods 2004; 292(1-2): 17-23. http://dx.doi.org/10.1016/j. jim.2004.05.009. PMid:15350508. 